\title{
FINANCIAL CAPACITY OF INDUSTRIAL ENTERPRISE
}

\author{
Tatiana NAZAROVA \\ National Technical University «Kharkiv Polytechnic Institute», Ukraine
}

\begin{abstract}
The purpose of the article is to determine the economic content of the category of financial capacity, the study of the influence of the main factors affecting the operation of the industrial enterprises financial potential, as well as the rationale for the selection of best management practices. For every Ukrainian industrial enterprise is an urgent problem of the formation of optimal financial resources to ensure the stable operation of the enterprise, financial stability and solvency. The question remains effective financial capacity management system, taking into account the current realities of the Ukrainian economy. The study highlighted the direction of the management process financial potential of the industrial enterprises. The components and elements of the financial potential of the control system and its functional units. Methodology. Data for the study were taken from scientific publications and legislation. The methods of general scientific knowledge, as well as integrated assessment models, is to develop and study the dynamics of the integral index, built on a clearly identified mechanism of mathematical relationships. Results. On the basis of a generalized approach to the definition of "financial potential" category author suggested his own definition of this category, offered economic components of financial capacity. Practical implication. The result of this study is on the direction of cash flow optimization in the enterprise at the expense of control financial flows. Formation of current funding matrix with the release of surplus area, and a balanced current funding deficit. Value/originality. On the basis of the study proved that the implementation of this approach facilitates the development of highquality management decisions on the development of a financial management plan for the financial flows in an industrial plant, consequently, will increase its competitiveness.
\end{abstract}

Key words: financial potential, industrial enterprise, financial stability, the current funding.

JEL Classification: L 00, G 17, G 39

\section{Introduction}

The problem of finding ways to strengthen the financial condition of industrial enterprises and optimize the management of its financial potential remains valid throughout the period of market relations in the Ukrainian economy. This is due, primarily, the lack of a unified methodology for comprehensive economic analysis and assessment of the financial condition of the financial potential of industrial enterprises.

Current economic conditions pose many industrial enterprise tasks to be quickly and efficiently addressed. This issue is to increase production, management of all types of resources, optimum capacity utilization. One of the main problems is the possibility of using its own financial capacity to respond quickly to changes in the external economic environment. As a result, the aspects of the research nature of the financial capacity of the company acquire relevance to maneuver financial resources effectively. The study aims are to clarify certain provisions within the methodological support of the financial potential management of industrial enterprises.

\section{The essence of the financial capacity of enterprises}

The problem of using Ukrainian industry financial capacity is becoming more urgent in terms of relentless globalization of the market. It generally emphasizes the importance of monitoring the state of business enterprises in terms of external and internal factors determining its activities and its financial capacity for sustainable development. In economic literature there is quite a clear interpretation of the category «financial capacity», that is why by analyzing the literature table the major existing definitions of this category was formed.

For the first time the concept of financial capacity was allocated by A. Volkov (1976). In his view, «financial potential is one of the resources of national income produced, which after all processes implemented redistribution of material and the material in the growth of the means of production». A. Volkov shared financial potential in absolute and relative. Absolute financial potential of advanced manufacturing is identified with the resources of national income produced. The relative financial potential of advanced production expressed as

Corresponding author:

${ }^{1}$ Department of International Management and Finance, National Technical University «Kharkiv Polytechnic Institute».

E-mail: taniya2009@list.ru 
a percentage of national income. Analyzing the literature in finance and financial management, we note the exact concept of financial potential of the company.

Each of the approaches are to define the essence of the financial potential of the enterprise is correct and describes the concept from different angles (Table 1).

Summary of scientific approaches formed the essence of the financial capacity of its position and made it possible to formulate the nature of the financial potential of industrial enterprises (Fig. 1)

\section{Optimization of financial flows of enterprises}

Engineering industry is the only industry that provides hardware, comprehensive mechanization and automation of production processes, promotes scientific and technological progress in all other sectors. For the efficient management sector in general and the management of individual machine-building enterprises in particular, it is necessary to identify problematic aspects of the industry and, consequently, their elimination. Experience in industrialized countries shows: that the industry is an indicator and a catalyst for industrial development. Functioning of engineering companies carried out under conditions of dynamic changes in the environment which is influenced by globalization processes strengthen economic, political factors, the global financial crisis etc. The economic situation of engineering for different periods of operation of the complex was investigated in the works of many local scientists and researchers. However,

Table 1

Defining the essence of the concept of «financial capacity» of the enterprise

\begin{tabular}{|l|l|}
\hline \multicolumn{1}{|c|}{ Author } & \multicolumn{1}{c|}{ The interpretation of the concept } \\
\hline Bykova V.G (2005, p. 56) & $\begin{array}{l}\text { This is the driving force required to transfer the company focused resources from the static state } \\
\text { to a dynamic that provides the most effective implementation of the goals and directions of the } \\
\text { company. }\end{array}$ \\
\hline Kuntcevich V.O. (2004, p. 123-124) & $\begin{array}{l}\text { This ability is to optimize the financial system with the involvement and use of financial resources. } \\
\text { Financial development potential of the enterprise - totality of the available financial resources, } \\
\text { system capabilities for their involvement and effective management to achieve tactical objectives } \\
\text { and company strategic goal - maximization enterprise value in the long period. }\end{array}$ \\
\hline Onishko S.V. (2003, p. 67-68) & $\begin{array}{l}\text { Financial Potential reflects not only familiarize oneself with available Financial resources, but their } \\
\text { reserves can be used under certain conditions. }\end{array}$ \\
\hline Stetsyuk P.A. (2007, p. 130) & Financial Potential in essence is greater than Financial Resources and includes the last. \\
\hline
\end{tabular}

The financial potential of the industrial enterprise is a dynamic characteristics of the enterprise business system, serving as a set of functional components that reflect the actual and potential businesses

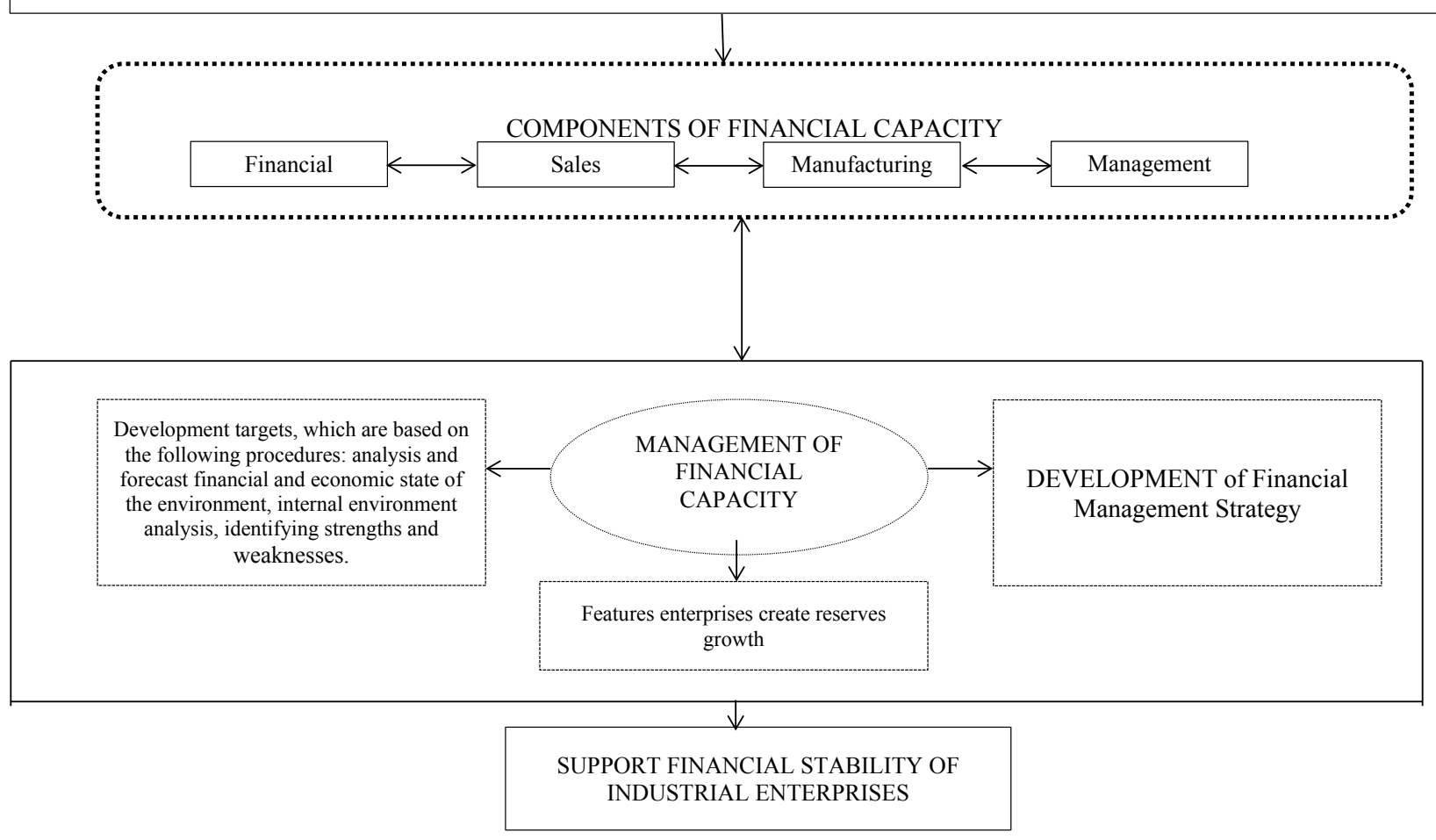

Fig. 1. The essence of the financial potential of industrial enterprises (author`s own development) 
dynamic changes in environmental conditions, increased globalization of the economy Ukraine necessitate analyzing the economic situation of mechanical engineering at the present stage of its development as creating systems industries.

In a sharp deterioration in economic conditions necessary to develop measures to improve the financial and economic security of industrial enterprises of all forms of ownership. It is necessary to develop the concept of large and medium industrial enterprises in Ukraine in terms of European integration. Implementation areas, contributing to the development of industrial enterprises will be difficult and almost impossible without a controlled mechanism of industrial enterprises, which will significantly improve the competitiveness of Ukrainian industrial enterprises with integration into the world economic system.

The financial stability of the company is largely determined by the level of synchronization in terms of flows of money and time. Effective cash management can reduce the need for businesses in debt. Actively managing cash flow can provide:

- More efficient and economical use their own financial resources generated from internal sources;

- Decrease of the enterprise development rate relation from the loans;

- Acceleration of the turnover;

- Reducing the risk of the company insolvency;

- Efficient use of temporarily free balances in the composition of current assets and accumulating of investment resources.

Using models of financial balance in order to ensure the solvency and liquidity of the company that is in crisis, aimed at increasing the incoming cash flow and reduce output. The increase in incoming cash flow is achieved through the following main activities:

1) mobilization of internal reserves of self-financing;

Table 2

Matrix of Current Financing

\begin{tabular}{|c|c|c|c|}
\hline \multicolumn{4}{|c|}{ Coverage ratio of current assets net working capital WOC /A } \\
\hline & $<0 \%$ & {$[0 \% ; 50 \%]$} & $>50 \%$ \\
\hline \multirow{9}{*}{ 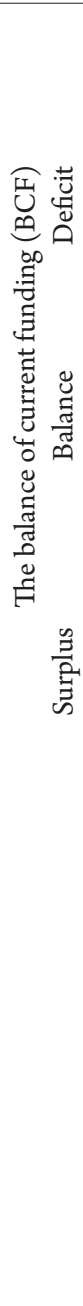 } & $\begin{array}{l}6 \text { Surplus of current funding. The } \\
\text { situation where investment in inventories } \\
\text { and receivables amount payable covered } \\
\text { irrationally, that there is excessive borrowing. } \\
\text { At the inefficient use of short-term loans, this } \\
\text { situation threatens significant losses related } \\
\text { to these loans cover and complete loss of } \\
\text { short-term liquidity. }\end{array}$ & $\begin{array}{l}5 \text { Surplus of current funding, } \\
\text { excessive borrowing money for a } \\
\text { short period. The situation may } \\
\text { affect the short-term liquidity }\end{array}$ & $\begin{array}{l}4 \text { The company has a sufficient size for } \\
\text { WOC finance their needs and your balance. } \\
\text { Surplus in the current funding WOC }>0 \\
\text { indicates inefficient use of its own funds. The } \\
\text { development of a competent financial policy } \\
\text { (short and long term investments), otherwise } \\
\text { the company is experiencing inflationary risk } \\
\text { and the risk of lost benefits }\end{array}$ \\
\hline & $\begin{array}{l}3 \text { Enterprise is too dependent on short-term } \\
\text { loans to finance their needs. This own funds } \\
\text { not enough. There is a high risk of losing the } \\
\text { current liquidity of losses }\end{array}$ & $\begin{array}{l}2 \text { Well-balanced situation, } \\
\text { rational credit policy and } \\
\text { effective short-term financing, } \\
\text { but such a situation is typical for } \\
\text { the current low level of liquidity. }\end{array}$ & $\begin{array}{l}1 \text { Current funding is well balanced with } \\
\text { sufficient liquidity. }\end{array}$ \\
\hline & $\begin{array}{l}9 \text { The deficit of current funding. In } \\
\text { the absence of its own working capital, } \\
\text { the company is also not able to finance } \\
\text { its current activity because the limited } \\
\text { involvement of short-term loans necessary to } \\
\text { use drastic measures to financial recovery. }\end{array}$ & $\begin{array}{l}8 \text { It is necessary to reduce the } \\
\text { amount of borrowing because } \\
\text { their coverage is not enough } \\
\text { money }\end{array}$ & $\begin{array}{l}7 \text { The company is not enough money to finance } \\
\text { their needs, therefore, in this situation, you must } \\
\text { either reduce the CFN (conducting effective } \\
\text { policy management of accounts receivable and } \\
\text { inventory, attract additional short-term loans) } \\
\text { or increase WOC (accumulation of additional } \\
\text { own short-term capital by reducing the dividend } \\
\text { increase authorized capital, sales of fixed assets } \\
\text { without causing harm to the principal activity) }\end{array}$ \\
\hline & \multicolumn{3}{|c|}{ To build the matrix, the following indicators were used: } \\
\hline & $\begin{array}{l}\text { their working capital of the company } \\
\text { (working capital) }\end{array}$ & \multicolumn{2}{|c|}{$W O C=$ current assets - Current liabilities } \\
\hline & $\begin{array}{l}\text { coverage ratio of current assets with net } \\
\text { working capital }\end{array}$ & \multicolumn{2}{|c|}{$C_{\text {cawc }}=W O C / A$ (Asset balance) } \\
\hline & current financial needs & $C F N=S+R E C-P A Y$ & $\begin{array}{l}\text { where } S \text { - stocks, } R E C, P A Y \text { - receivables and } \\
\text { payables }\end{array}$ \\
\hline & $\begin{array}{l}\text { The balance of current funding }(\mathrm{BCF}) \text { is an } \\
\text { indicator of the balance of current financial } \\
\text { requirements and sources of funding: }\end{array}$ & \multicolumn{2}{|c|}{$B C F=W O C-C F N$} \\
\hline & \multicolumn{3}{|c|}{ Square 1,2,3 - Balance; Square 4,5,6 - Excess; Square 7,8,9 - deficit. } \\
\hline & where $\mathbf{G}=\left(G_{1}, G_{2}, \ldots . G_{u}\right)^{T}-$ center & $\begin{array}{l}\text { The calculation of the integral ind } \\
I_{j}=\left(I_{j}=\left(G_{j 1}-G_{j 1}^{\min }\right) /\left(G_{j 1}^{\max }-G_{j 1}^{\min }\right)\right. \\
\text { ed and normalized column vector o }\end{array}$ & $\begin{array}{l}\text { ex } \\
\text { (1) } \\
\text { f uncorrelated principal components }\end{array}$ \\
\hline
\end{tabular}


2) refinancing of receivables;

3) sales promotion of primary products;

4) attracting additional joint stock (equity) capital;

5) obtaining new loans.

Initial cash flow decreased due to the following measures:

1) reduce current payments under operating activities (reducing production costs);

2) restructuring of account payable;

3) review the dividend policy;

4) investment freeze.

Ensuring the growth potential of the financial industry on the basis of a comprehensive evaluation and predictive factors by introducing structural matrix of current financing (CF) (Table 2), with zones: surplus and a balanced current funding deficit. The control of financial flows is based on a matrix of current financing.

Definite integral index of financial capacity of industrial enterprises ( $\mathrm{Ij}$ ) enables businesses to rank in terms of financial capacity, depending on their position in the matrix of current funding (Table 2). It was established that the companies that have a high rating, effectively carry out the operational management of current assets and short-term liabilities. With taking into assessment stage of development companies on the basis of calculation allows for scenario using the whole arsenal of tools, among which is dominated by tactical and budget planning. Of particular relevance this aspect of financial flows acquires to companies that are in the early stages of their life cycle, where access to external financing sources are limited. Thus, the development of a financial plan should include priority: development of management measures for improving the management of financial flows of the company.

\section{Conclusion}

Under the financial potential should be understood the capabilities of financial resources and competencies of industrial enterprise solution to provide current and strategic tasks aimed at sustainable operation and development of the company. It defines the financial position of the company, its solvency and liquidity, level of social protection of workers, the development of technology base; can objectively evaluate the financial capacity to ensure at all stages of the high level of competitive advantage. For receiving the greatest possible effect on the financial capacity it should be managed with modern tools to be implemented in the financial policy of the company. While its developing should be taken into account that the basis for the formation of the financial potential of the company have the financial resources and opportunities for their formation and effective use. Proper evaluation stage of the company, its financial resources and their effective use, forecast results will develop only right scenario using the entire arsenal of tools, among which is dominated by tactical and budgeting, financial instruments. Proved that the basic characteristic of the process of determining the financial capacity of the industrial enterprise is to assess financial condition. For this purpose, supplemented with scientific and practical approach to evaluating the effectiveness of the implementation strategy for the growth of financial potential, based on a comprehensive and predictive assessment of factors affecting the level of financial potential of industrial enterprises, and indicators characterizing the financial potential, forming a matrix of current funding allocation zone surplus and a balanced current funding deficit.

\section{References:}

Bykova. V.G. (2005). Finance and Economic Potential of national importance - evaluation and management. Finance Ukraine, № 6, p. 56-61.

Dorofeev M.L. (2011). Practical aspects of the matrix to optimize the current financing. Publishing the Russian Economic University of Plekhanov, № 4, p. 115-125.

Kuntcevich V.O. (2004). The concept of financial potential of the company and its evaluation. Recent economic problems. № 7(37), p. 123-130.

Onishko S.V. (2003). Financial innovation potential of the economy. Finance Ukraine, № 6, p. 67-74.

Sablina N.V. (2015). Methodological approaches to the financial potential of the enterprise. Recent economic problems, №4 (166), p. 123-131.

Shumska S.S. (2007). The financial potential of Ukraine, methodology and evaluation. Finance Ukraine, № 5, p. 55-64.

Stetsyuk P.A. (2007). The economic nature of financial resources. Finance Ukraine, № 1, p. 129-143.

Yudin M.A. (2009). Financial potential engineering enterprise. Industrial Economy, № 48 (5), p. 47-52.

Volkov A.M. (1976). Long-term planning of financial resources. city Moscow, Russia: monograph, 174 p.

Zaruba V.Y. (2012). Modeling financial management of the enterprise potential. Problems of Economics, № 2, p. 33-37. 
Vol. 2, No. 3, 2016

\section{Татьяна НАЗАРОВА}

\section{ФИНАНСОВЫЙ ПОТЕНЦИАЛ ПРОМЫШЛЕННОГО ПРЕДПРИЯТИЯ}

Аннотация. Целью статьи является определение экономического содержания категории финансовый потенциал, исследование влияния основных факторов влияющих на управление финансовым потенциалом промышленного предприятия, а также обоснование выбора наиболее оптимальных методов управления. Для каждого украинского промышленного предприятия является актуальной проблема формирования оптимального объема финансовых ресурсов для обеспечения стабильной работы предприятия, финансовой устойчивости и платежеспособности. Остается открытым вопрос результативной системы управления финансовым потенциалом с учетом нынешних реалий украинской экономики. В результате исследования выделены направления процесса управления финансовым потенциалом промышленного предприятий. Определены составляющие и элементы системы управления финансовым потенциалом, его функциональные звенья. Методология. Данные для исследования были взяты из научных публикаций и законодательной базы. Использованы методы общенаучного познания, а также интегральные модели оценки, заключающиеся в создании и исследовании динамики интегрального показателя, построенного на четко оговоренном механизме математических зависимостей. Результаты. На основе обобщения подходов к определению категории «финансовый потенциал» автором предложено собственное определение этой категории, предложены экономические составляющие финансового потенциала. Практическое значение. Результатом исследования является направления по оптимизации движения денежных потоков на предприятии за счет контроля финансовых потоков. Формирование матрицы текущего финансирования с выделением зоны излишков, сбалансированного текущего финансирования и дефицита. Значение/оригинальность. На основе проведенного исследования обосновано, что реализация данного подхода способствует разработке качественных управленческих решений по разработке финансового плана по управлению финансовыми потоками на промышленном предприятии, что, в последствии, повысит его конкурентоспособность. 